УДК 657.635.658.15

JEL Classification: M42

C. В. СЕЛIЩЩЕВ,

кандидат економічних наук асистент Національного џентту обліку та аудиту, Національна академія статистики, обліку та аудиту

\title{
Організація аудиту безперервності діяльності державних підприємств
}

В статті досліджено основні фактори, ио впливають на погіриення економічного стану держсавних підприємств та можуть спричинити припинення ӥх діяльності. Особливу увагу приділено організації аудиту держсавних підприсмств, основаного на попередній оцінці ризику припинення діяльності. Надано практичні рекомендацій щодо побудови плану та програми аудиту.

Ключові слова: державне підприємство, фактори, організсчія аудиту, аудиторський ризик.

Постановка проблеми. Успішна реалізація будь-яких муніципальних проектів формування і реформування галузей економіки потребує ефективно організованого загальнодержавного економічного контролю, який здійснюється в Україні державної аудиторсыкою службою [1]. Від того, наскільки високоякісною буде інформація про фінансово-економічний стан суб ${ }^{\prime}$ єктів господарювання державної форми власності та їх здатність продовжувати діяльність у найближчому майбутньому, яка надається системою урядового економічного контролю, в значній мірі залежить аргументованість рішень щодо різних аспектів загальнодержавної фінансово-економічної політики, фінансово-господарської роботи муніципальних установ, організацій 3 державною участю, особливо пов'язаних з діяльністю країни, або таких, діяльність яких має особливе значення для країни.

Аналіз досліджень і публікацій. Актуальності у цьому сенсі набувають дослідження, спрямовані на подальше розроблення та адаптацію загальнонаукових підходів до організації аудиту, висвітлених у працях вітчизняних та зарубіжних вчених [1-9].

Метою статті є дослідження та систематизація факторів впливу на організацію аудиту безперервності діяльності підприємств державного сектору економіки.

Виклад основного матеріалу дослідження. Як правило, першим, підготовчим етапом аудиторської перевірки вважається знайомство аудитора 3 економічним суб' єктом. Аудитору слід розглянути дані про роботу суб' єкта господарювання з метою обгрунтованого складання плану проведення аудиторської перевірки [3].

Проведені дослідження вказують, що державним підприємствам притаманні особливості, обумовлені характером управління в державному секторі економіки та галузевою специфікою їх діяльності.

Аналіз поточної практики дозволяє припустити, що найбільш суттєвими факторами погіршення економічного стану підприємств державного сектору, які можуть спровокувати ризик припинення їх діяльності, $є$ :

1) Організаційно-управлінські проблеми виробництва:

- вплив бюрократичного компонента на формування цілей;

- лімітування матеріальних витрат за видом і якістю (закупівельні специфікаціі);

- вплив суспільно-політичної складової на прийняття економічних рішень;

- низький ступінь схильності до ризику (акцент на формальні процедури);

- бажання керівників державних компаній збільшити обсяги власного бюджету.

2) Особливості стимулювания праці:

- низький рівень заробітної плати порівняно з приватним сектором;

- брак систем оплати праці, спрямованих на стимулювання ефективності;

(C) С. В. Селіщев, 2017 
- складність встановлення результатів роботи державних службовців;

- корупція.

3) Особливості галузевої конкурентної боротьби:

- відсутність конкуренції;

- бюрократична монополія на окремі галузі економіки.

Аудитору доцільно здійснити попередню оцінку наявності та ступеня впливу зазначених факторів на ризик припинення діяльності державного підприємства. На основі розробленої системи запропоновано авторський підхід до оцінки ризиків (табл. 1).

Таблиця 1

Оцінка ризику припинення діяльності державного підприсмства

\begin{tabular}{|l|c|c|}
\hline \multicolumn{1}{|c|}{ Показник } & $\begin{array}{c}\text { Оцінка } \\
\text { показника, } \\
\text { балів }\end{array}$ & $\begin{array}{c}\text { Оцінка ризику } \\
\text { припинення } \\
\text { діяльності }\end{array}$ \\
\hline Залежність від дотацій & 2 & низький \\
\hline Динаміка показників економічного розвитку & 8 & високий \\
\hline Адекватність інвестицій & 1 & низький \\
\hline $\begin{array}{l}\text { Адекватність співвідношення між показниками } \\
\text { збільшення організації та обсягами виробленої } \\
\text { продукції / наданих послуг }\end{array}$ & 5 & середній \\
\hline $\begin{array}{l}\text { Ступінь сторонньої регламентації використовуваних } \\
\text { матеріалів }\end{array}$ & 2 & низький \\
\hline $\begin{array}{l}\text { Відсутність залежності від зміни політичної ситуації } \\
\text { в країні }\end{array}$ & 10 & високий \\
\hline $\begin{array}{l}\text { Адекватність масштабів документообігу та наявність } \\
\text { системи делегування повноважень }\end{array}$ & 3 & низький \\
\hline Ефективність використання бюджетних коштів & 8 & високий \\
\hline Відповідність персоналу посадовим вимогам & 2 & низький \\
\hline Конкурентоспроможність розміру заробітної плати & 4 & середній \\
\hline Наявність систем стимулювання праці & 8 & високий \\
\hline Зловживання посадовими обов'язками & 8 & високий \\
\hline $\begin{array}{l}\text { Переважання формалізму при виконанні робочих } \\
\text { операцій) }\end{array}$ & 3 & низький \\
\hline Конкурентне середовище & 3 & низький \\
\hline
\end{tabular}

Джерело: авторська розробка

За даними табл. 1 визначено найбільш індикативні показники збільшення ризику припинення діяльності. Таким чином, питома вага часу, запланованого на проведення процедур по суті, у сукупному часі проведення аудиту, визначатиметься питомою вагою ступеня ризику, розрахованою в результаті попередніх аудиторсыких процедур оцінки зазначених показників, у сукупному ризику.

Наступним етапом аудиторської перевірки $\epsilon$ складання плану аудиту, яке передбачає дотримання єдиної стратегії і чітке визначення характеру, термінів виконання та змісту аудиторських процедур.

Планування дозволяє виявити можливі труднощі, гарантувати умови, за яких робота буде виконана 3 оптимальними витратами, на належному рівні і у встановлений термін. Складання плану надає можливість продуктивно розподіляти роботу між членами аудиторської групи і координувати ії виконання. За результатами планування формується програма, в якій зазначаються об'єкти аудиту, ау диторські процедури по суті, запланований період обстеження кожного об'єкта аудиту, виконавці. 
Планування включає кілька стадій:

1) формування стратегії перевірки;

2) попередній аналіз ризиків економічного суб' єкта;

3) формування складу аудиторської групи;

4) розрахунок ціни послуг;

5) попередній аналіз системи внутрішнього контролю та обліку суб'єкта господарювання.

Виходячи 3 даних попередньої оцінки ризиків (табл. 1) для розроблення плану та розрахунку часу перевірки ймовірності припинення діяльності організації, пропонуємо умовно позначити високий ризик як 1 , середній -2 , високий -3 . Таким чином, сумарний показник дорівнюватиме 25 . Тепер можна розрахувати відсоток часу для перевірку кожного об'єкта: $100 \% / 25=4 \%$. Отже, на перевірку об'єкта 3 низьким ризиком необхідно запланувати 4\% від сукупного терміну перевірки, а для об'єкта з високим рівнем ризику $-12 \%$, відповідно.

План перевірки ймовірності припинення діяльності організації на основі наведених више розрахунків подано у табл. 2.

Таблиця 2

План перевірки (виявлення) результатів, спричинених факторами погіршення економічного стану підприсмств державного сектору

\begin{tabular}{|l|c|}
\hline \multicolumn{1}{|c|}{ Об'сккт } & $\begin{array}{c}\text { Чaс } \\
\text { (відсоток } \\
\text { від сукупого } \\
\text { терміну } \\
\text { перевірки) }\end{array}$ \\
\hline Динаміка показників рентабельності & $4 \%$ \\
\hline Динаміка обсягів виробництва/надання послуг & $12 \%$ \\
\hline Інвестиційні плани/договори & $4 \%$ \\
\hline $\begin{array}{l}\text { Співвідношення між показниками збільшення організації та обсягами } \\
\text { виробленої продукціі/ наданих послуг }\end{array}$ & $8 \%$ \\
\hline Доцільність та обгрунтованість використовуваних матеріалів & $3 \%$ \\
\hline Залежність від зміни політичної ситуації в країні & $4 \%$ \\
\hline $\begin{array}{l}\text { Оцінка масштабів документообігу та наявність системи } \\
\text { делегування повноважень }\end{array}$ & $12 \%$ \\
\hline Ефективність використання бюджетних коштів & $4 \%$ \\
\hline Відповідність персоналу посадовим вимогам & $12 \%$ \\
\hline Рівень заробітної плати & $4 \%$ \\
\hline Наявність систем стимулювання праці & $8 \%$ \\
\hline Наявність ознак зловживання посадовими обов'язками & $12 \%$ \\
\hline Переважання формалізму при виконанні робочих операцій) & $4 \%$ \\
\hline Конкурентне середовище & $4 \%$ \\
\hline
\end{tabular}

Джерело: авторська розробка

Виходячи 3 практичного досвіду проведення аудиту для групи з трьох аудиторів і терміну перевірки 40 робочих днів можна запропонувати програму перевірки (виявлення) результатів, спричинених факторами погіршення економічного стану підприємств державного сектору (табл. 3).

На третьому, головному етапі здійснюється власне процес проведення аудиту. В процесі здійснення головного етапу аудитор може змінювати значення обчислених показників (за необхідності) і встановлювати виправлені значення величини ризику та інших показників.

Головний етап охоплює: виконання процедур по суті і корекцію розрахунків, зроблених на етапі планування. 
Програма перевірки (вияв.лення) результатів, спричинених факторами погіршення економічного стану підприємств державного сектору

\begin{tabular}{|c|c|c|c|}
\hline No & Об'єкт & Процедура & $\begin{array}{c}\text { Час } \\
\text { (год.) }\end{array}$ \\
\hline \multicolumn{4}{|c|}{ Eman 1 } \\
\hline 1 & Динаміка показників рентабельності & $\begin{array}{l}\text { Перевірка, перерахунок, } \\
\text { аналітичні процедури }\end{array}$ & \\
\hline 2 & $\begin{array}{l}\text { Динаміка обсягів виробництва/надання } \\
\text { послуг }\end{array}$ & $\begin{array}{l}\text { Перевірка, перерахунок, } \\
\text { аналітичні процедури }\end{array}$ & \multirow{2}{*}{190} \\
\hline 3 & $\begin{array}{l}\text { Ефективність використання бюджетних } \\
\text { коштів }\end{array}$ & $\begin{array}{l}\text { Перевірка, оцінка, перерахунок, } \\
\text { повторне виконання }\end{array}$ & \\
\hline \multicolumn{4}{|c|}{ Eman 2} \\
\hline 1. & $\begin{array}{l}\text { Співвідношення між показниками } \\
\text { збільшшення організації та обсягами } \\
\text { виробленої продукції/ наданих послуг }\end{array}$ & $\begin{array}{l}\text { Оцінка, перерахунок, } \\
\text { аналітичні процедури }\end{array}$ & \multirow{3}{*}{140} \\
\hline 2. & $\begin{array}{l}\text { Доцільність та обгрунтованість } \\
\text { використовуваних матеріалів }\end{array}$ & $\begin{array}{l}\text { Ідентифікація, оцінка, } \\
\text { повторне виконання }\end{array}$ & \\
\hline 3. & Інвестиційні плани/договори & $\begin{array}{l}\text { Дослідження, аналітичні } \\
\text { процедури }\end{array}$ & \\
\hline \multicolumn{4}{|c|}{ Eman 3} \\
\hline 1. & Оцінка масштабів документообігу & $\begin{array}{l}\text { Аналітичні процедури, запит, } \\
\text { ідентифікація, нагляд }\end{array}$ & \multirow{8}{*}{570} \\
\hline 2. & $\begin{array}{l}\text { Відповідність персоналу посадовим } \\
\text { вимогам }\end{array}$ & $\begin{array}{l}\text { Ідентифікація, оцінка, } \\
\text { аналітичні процедури }\end{array}$ & \\
\hline 3. & Рівень заробітної плати & $\begin{array}{l}\text { Аналітичні процедури, } \\
\text { підтвердження }\end{array}$ & \\
\hline 4. & Наявність систем стиму лювання праці & Ідентифікація, оцінка & \\
\hline 5. & $\begin{array}{l}\text { Наявність фактів зловживання } \\
\text { посадовими обов'язками }\end{array}$ & Ідентифікація, оцінка & \\
\hline 6. & $\begin{array}{l}\text { Переважання формалізму при виконанні } \\
\text { робочих операцій) }\end{array}$ & $\begin{array}{l}\text { Ідентифікація, оцінка, } \\
\text { аналітичні процедури }\end{array}$ & \\
\hline 7. & Конкурентне середовище & Ідентифікація, оцінка & \\
\hline 8. & $\begin{array}{l}\text { Залежність від зміни політичної ситуації } \\
\text { в країні }\end{array}$ & Запит, аналітичні процедури & \\
\hline
\end{tabular}

Джерело: авторська розробка

Висновки. В результаті дослідження поточної практики нами визначено характерні риси суб' єктів господарювання в державному секторі, які виокремлюють ї із приватного сектору. Такі риси зумовлюють необхідність модифікації підходів до

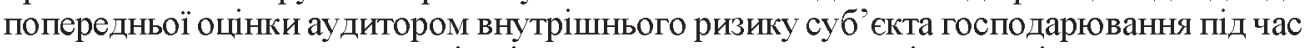
планування, зокрема в аспекті оцінки ризику припинення діяльності.

В ході дослідження було запропоновано підходи до виявлення і оцінки елементів внутрішнього ризику суб' єкта господарювання державного сектору економіки, зокрема пов'язаних із припиненням діяльності, та надано пропозищії щодо побудови плану та програми проведення аудиту.

Такий підхід дозволить знизити ризик невиявлення та оптимізувати витрати часу та ресурсів на проведення перевірки.

\section{Список використаних джерел}

1. Данилевский Ю. А. та ін. Аудит: учеб. пособ. М.: ИД ФБК-ПРЕСС, 2000. 544 с.

2. Бутинець Ф.Ф. Аудит і ревізія підприємницької діяльності: навч. посіб. Житомир: ППП «Рута», 2001. $416 \mathrm{c}$.

3. Гончарук Я. А., Рудницыкий В. С. Аудит: навч. посіб. Львів: Світ, 2002. 296 с. 
4. Давидов Г. М. Аудит: підруч. К.: Ліга, 2004. 336 с.

5. Кулаковська Л. П., Піча Ю. В. Організація і методика аудиту: підручник. К.: Каравела, 2009. 544 с.

6. Петрик О. А Аудит: методологія та організація: моногр. К.: КНЕУ, 2003. 260 с.

7. Проскуріна Н. М. Процедурне забезпечення аудиту. Теорія та практика: моногр. К.: ДП «Інформ.-аналіт. агентство», 2011. 739 с.

8. Редько А. Ю. Аудит в Україні. Морфологія: моногр. К.: ДП «Інформ.-аналіт. агентство», 2008. 493 с.

9. Савченко В. Я. Аудит: навч. посіб. К.: КНЕУ, 2002. 322 с.

10. Про затвердження Положення про Державну аудиторську службу України: постанова Кабінету Міністрів України від 3 лютого 2016 р. № 43.URL: http://zakon2. rada.gov.ua/laws/show/43-2016-\%D0\%BF

С. В. СЕЛИЩЕВ,

кандидат экономических наук, ассистент Нациионального центра учета и аудита, Национальная академия статистики, учета и аудита

\section{Организация аудита непрерывности деятельности государственных предприятий}

В статье исследованы основные факторы, которые влияют на ухудиение экономического состояния государственныц предприятий и могут повлечь прекрапеене их деятельности. Особое внимание уделено организации аудита государственных предприятий, основанного на предварительной оченке риска прекращения деятельности. Представлены практические рекомендации по построению плана и программы судита.

Ключевые слова: государственное предприятие, факторы, организация аудита, аудиторский риск.

S. V. SELISHCHEV,
PhD (Economics),
Assistant of National Center for Accounting and Audit,
National Academy of Statistics, Accounting and Audit

\section{Organizing Audit of Business Continuity in Public Enterprises}

Quality of information on financial and economic situation at public enterprises and their capability to continue operation in the near future, supplied by the government bodies of economic control, has strong implications for the soundness of decisions on macroeconomic and financial policy, financial and economic performance of municipal institutions and entities with government participation. The main factors that affect the economic situation at public enterprises and may result in termination of their operation are studied, with emphasis on audit of public enterprises, based on the preliminary evaluated risk of termination of their operation. Practical recommendations on planning and programming of audit are given.

The analysis of current practices allows for identifying the specific features of public enterprises, distinguishing them from private sector. These features necessitate modifications in auditor's approaches to preliminary assessment of the internal risk of an enterprise in audit planning, especially when planning assessment of the risk of business termination. This approach will reduce the risk of non-detection, associated with the probability of business termination at a public enterprise, and optimize the time and resources required for andit..

Key words: public enterprise factors, organization of audit, audit risk.

Посилання на статтю:

Селіщев С. В. Організація аудиту безперервності діяльності державних підприємств // Науковий вісник Національної академії статистики, обліку та аудиту: зб. наук. праць. 2017. №1-2. С. 35-39. 